\title{
Does The World, After the Corona Crisis, need to Design Coherent, Flexible and Sustainable Economic Systems?
}

\author{
Al-Mafrachi Mustafa Saad ${ }^{1}$, Enas Hussein Aboura ${ }^{2}$, Abed, Hanaa Najm ${ }^{3}$ \\ ${ }^{1}$ The Bucharest University of Economic Studies, Bucharest, Romania, Nationality: Iraqi \\ ${ }^{2}$ The Bucharest University of Economic Studies, Bucharest, Romania, Nationality: Palestine \\ ${ }^{3}$ University of Agriculture and Veterinary Medicine, Bucharest, Romania, Nationality: Iraqi
}

\begin{abstract}
.
This research paper aimed to analyze the impact of the Corona pandemic on the economic, health and political governance systems in the world by examining the fate of what humankind has accomplished within the framework of its overlap and possibly economic integration in the past three decades, and then the study began to ask questions about: Will the Corona pandemic be the beginning To restore the economic and service systems of the world countries? Or will the size of global interference in all areas, especially the economic one, prevent the disengagement of world countries and their current systems? And will the United States remain at the forefront of the international system? Will the European Union maintain its cohesion? Will China abandon its gradual rise and become more equitable? What will the international system be after the Corona pandemic? Does the crisis represent an opportunity to build governance systems capable of dealing with non-traditional challenges? in addition to a number of Other questions. The study reached a number of results, including: The crisis revealed the urgent need for international intervention, whether to impose isolation, monitor patients, and expand health diagnosis, or through its strong return to the health sector, such as building and equipping public hospitals. It has become accepted that the international system has been witnessing multi-polarity for years, and that the Corona pandemic has only entrenched an international reality that is already in the process of forming while giving more opportunities for the rise of China.
\end{abstract}

Keywords: Corona, international system, the global economy, the rise of China, the American hegemony. 


\section{Introduction:}

The Corona pandemic crisis revealed major imbalances in the health, economic and political governance systems in many countries of the world, and major countries have not escaped from this rapidly spreading pandemic due to the unwillingness of their systems to deal with such crises, while poor countries with modest infrastructure have proven their skill in coordination. And the mobilization of its human energies to face the danger of its spread ${ }^{1}$.

Figure 1: Global Economic Impact of Covid -19

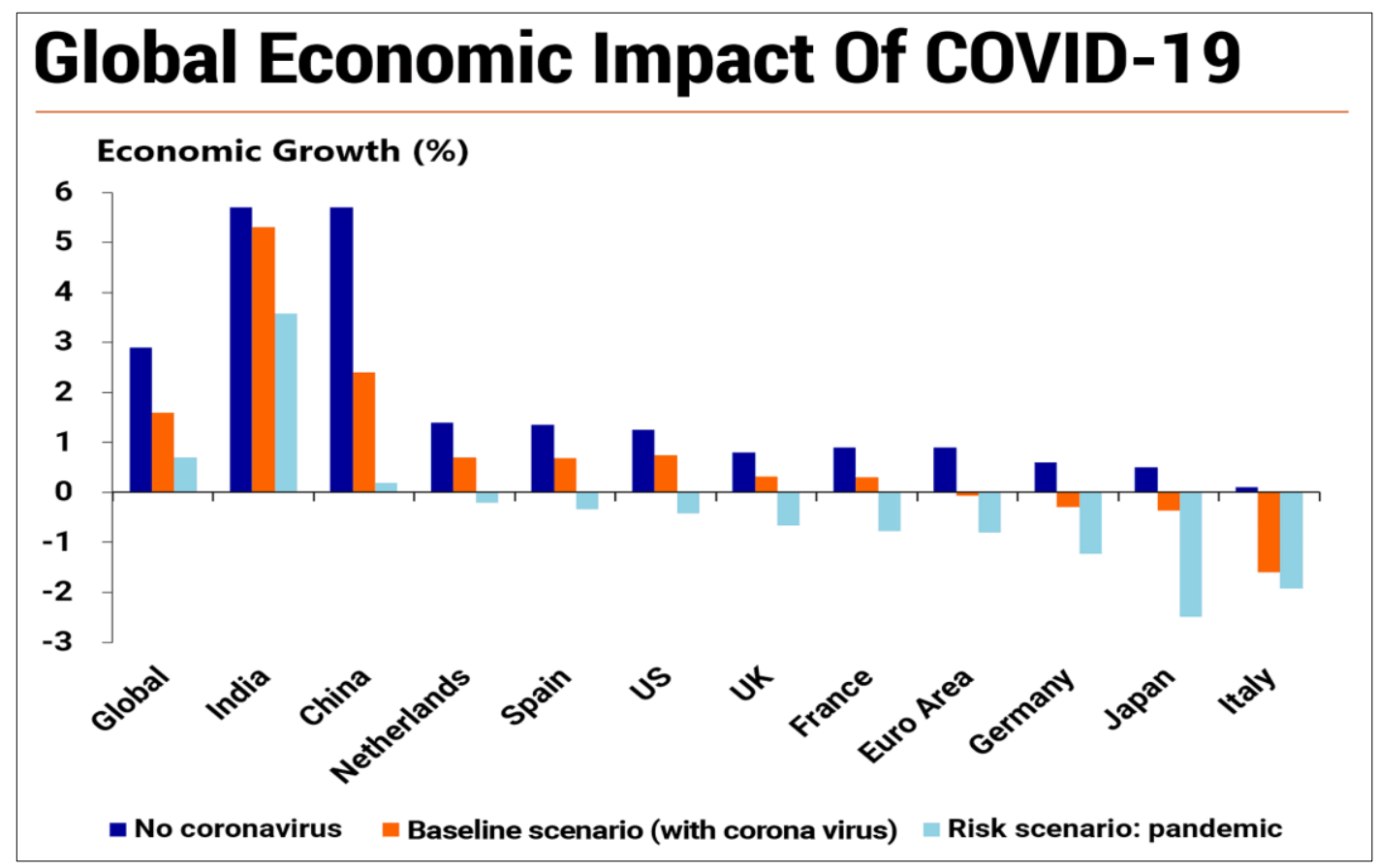

Source: Bloomberg website ${ }^{2}$

The previous figure (Figure 1) shows the expectations of the global economic slowdown due to Covid 19, as this graphic indicated that the rate of global economic growth has decreased to $1.6 \%$ compared to the expectations of the Economic Cooperation Organization, which put the global economy at $2.4 \%$, while the Bloomberg agency was More optimistic and favored the global economy to grow by $2.7 \%$.

1 OECD Policy Responses to Coronavirus (COVID-19), The territorial impact of COVID-19: Managing the crisis across levels of government, 10 Nov 2020. Available at: http://www.oecd.org/coronavirus/policy-responses/theterritorial-impact-of-covid-19-managing-the-crisis-across-levels-of-government-d3e $314 \mathrm{e} 1 /$

2 Hugo Erken, Raphie Hayat, Kan Ji, Coronavirus: The Economic Impact Of COVID-19 On India, 13/ 3/ 2020. Read more at: https://www.bloombergquint.com/opinion/coronavirus-the-economic-impact-of-covid-19-on-india 


\section{Where is the world heading after Corona?}

The world after Corona will not be the same as the world before it, the economies of countries will recover to varying degrees determined by the ability to respond to the needs of the next stage, and the priorities of spending and investment will change and the perception of individuals for life systems that have been accustomed to, and then a set of questions arise related to the fate of what humanity has accomplished within the framework of its overlap and perhaps Its economic integration in the past three decades, will the Corona pandemic be the beginning of the restoration of the economic and service systems in the countries of the world? Or will the size of global interference in all fields, especially the economic front, prevent the disengagement of the world's countries and their current systems? And will the United States of America remain at the forefront of the system? International? Will the European Union maintain its cohesion? Will China abandon its gradual rise and become more equitable? What will the international system be after the Corona pandemic? Does the crisis represent an opportunity to build governance systems capable of dealing with non-traditional challenges? About the rise of the pattern of nation-states capable of knowing all the limitations, a reality that must be dealt with? What is the fate of regional blocs, especially as they have proven to be useless in dealing with the crisis? Is there room to reproduce a globalization based on cooperation frameworks in areas of a humanitarian character, especially in light of the laxity of the risk management system in achieving the required balances in a number of non-traditional issues such as financial crises, climate change and health protection, leading to the spread of epidemics and the diversity of their strains? Does the current pandemic represent a pause? To reconsider the state of combined dependence that globalization has left behind from a proliferation that cannot be compressed or contained to many international crises?

\section{General framework of the study:}

\subsection{Thinking about returning to the nation-state in light of the decline in the influence of the liberal state:}

The Corona pandemic crisis restored a degree of confidence between citizens and the state, and even helped to think about returning to the nation state in light of the decline in the influence of the liberal state, and the need for the welfare state or the social welfare state has also become urgent, especially since the central nation states have proven that they are the most capable of dealing with The critical crises threatening the survival of peoples in the absence of mechanisms of cooperation and regional and international integration ${ }^{3}$.

The Corona crisis also revealed the urgent need for international intervention, whether to impose isolation or monitor patients and expanded health diagnosis, or through its strong return to the health sector, such as building and equipping public hospitals, harnessing the security services and the army to perform this task, or in the injection of funds to support companies and support the affected groups. From the crisis ${ }^{4}$. Perhaps these developments have raised new questions related to the type of political regimes and their utility in dealing with the crisis. Authoritarian or semi-

Jan Zielonka, Has the coronavirus brought back the nation-state?, Social Europe, 26 Mar 2020, Available at: https://www.socialeurope.eu/has-the-coronavirus-brought-back-the-nation-state

SCCM Resources, United States Resource Availability for COVID-19, SCCM, 5 Dec 2020, Available at: https://www.sccm.org/Blog/March-2020/United-States-Resource-Availability-for-COVID-19 
authoritarian states have had little difficulty in implementing this policy. As for democracies and quasi-democracies, the form and nature of intervention opened new horizons about the nature of the future role of the state, the controls of its intervention, and the limits of this. Interference in the face of personal and civil liberties, and thus will the future witness a further trend towards the centralization of the state in exchange for what is known as the minimum level of the state?

The truth is that the state was not absent in the first place until it is said that it has returned, but it is more correct that it is about to re-spread, so using artificial intelligence to monitor the extent of citizens 'commitment to quarantine and summoning armies even in established democracies to support health staff and build hospitals and health centers after they had set their sights on external threats to transform I directed it to protect the home front, implement curfews, prosecute violators, and carry out cleansing operations in streets and public places, all of which are features of new roles that countries of all kinds will witness with the decline of neoliberalism and capitalism $^{5}$. The question remains of the feasibility of the welfare state to rehabilitate that idea at the present time after decades of neoliberal control over people and the economy?

\subsection{The international system and the phenomenon of a return to multipolarity:}

It has come to be recognized that the international system has been witnessing multi-polarity for years, and that the Corona pandemic has only entrenched an international reality that is already in the process of forming while giving more opportunities for the rise of China and the decline of the United States of America ${ }^{6}$.

However, this does not necessarily mean that China will automatically replace the United States of America, rather it is more likely that the United States will remain at the forefront of global leadership for decades to come, but many analyzes have indicated that one of the repercussions of globalization is the shifting of the global balance of power from West to East according to standardize countries towards remedying the repercussions of the current pandemic. While the West was betting on containing China and benefiting from the enormity of its market by gradually integrating it into the global capitalist system, China has succeeded in containing the West and assimilating it, taking advantage of its demographic magnitude and its cultural and linguistic immunity instead of being contained and assimilated into the liberal system ${ }^{7}$. It seems that the international system is now witnessing the reality of new international balances, especially since the Corona pandemic highlighted the United States' need for China in the field of sanitary equipment, simple protective tools, and others. Although it cannot be assured that China has fully surpassed the crisis, it is certain that it has made important strides in controlling the epidemic and limiting its

5 Ottavio MARZOCCHI, Policy Department for Citizens' Rights and Constitutional Affairs, THE IMPACT OF CORONAVIRUS MEASURES ON DEMOCRACY, RULE OF LAW AND FUNDAMENTAL RIGHTS IN THE EU, (An overview of the measures taken by EU Member States), Manuscript completed in June 2020, P: 7 - 8, Available

via: https://www.europarl.europa.eu/cmsdata/211286/Overview\%20Covid\%20Measures\%20DRF\%2014\%20LIBE.pdf

6 Suzanne Xiao Yang, Complexity in China's current role in multilateral orders, China International Strategy Review volume 2, pages288-305(2020), 22 November 2020.

7 Xue Li, Cheng Zhangxi, Will China Replace the US Global Role?, the diplomat, 28 April 2018, Available at: https://thediplomat.com/2018/04/will-china-replace-the-us-global-role/ 
spread, and most importantly of all, it has created an image of itself in the world as a strong, resolute and able country to overcome crises, Rather, the Chinese machine began to move abroad to activate its soft power by sending medical teams, medicines, masks, health devices, etc. to African and Arab countries and even to some European countries themselves. All this means that China will advance in terms of economic competitiveness more along with strengthening its international presence, and this will certainly be at the expense of the US position in the international arena ${ }^{8}$.

But the most dangerous sign of the Corona pandemic is the continuing competition of major powers for international influence that threatens to undermine the ability of the globalized system to develop mechanisms to recover from, or at least contain, its most dangerous crises. This was evident in the inability to develop a coordinated global effort to develop treatments to counter the virus, and rather, the development of these treatments has become part of these international competition dynamics ${ }^{9}$.

In addition, the Corona crisis confirmed the limited international preparedness to provide adequate support necessary to confront the hotbeds of the disease or organize coordinated precautionary measures, which threatens to revert to isolationist illusions that open the way to an uncontrolled global conflict ${ }^{10}$.

\section{3. What is the fate of regional blocs and international institutions?}

The global spread of the Corona pandemic has raised - up to now - a national and international inability to confront it, which highlighted many questions and concerns about the efficiency and feasibility of the international globalization system, while national health systems in coherent and scientifically developed countries stood unable to confront this virus to the point of the collapse of some of these Regimes, the countries of the modern international cooperation system have almost disappeared through the United Nations institutions and organizations, but these institutions have become the subject of severe suspicion, as is the case with the World Health Organization ${ }^{11}$.

The Corona pandemic crisis also revealed the failure of the international and national systems and regional blocs to deal with the health challenge caused by the rapid spread of the virus and the lack of accurate scientific knowledge about $i^{12}$. On the state of rift in the structure of the union in conjunction with the trends of national and right-wing currents towards closing in on oneself and focusing on the national interest without considering considerations of regional responsibility, in parallel with the rise of waves of national populism behind the walls of national

8 Report of the WHO-China Joint Mission on Coronavirus Disease 2019 (COVID-19), 16-24 February 2020, P; 24, Available at: https:/www.who.int/docs/default-source/coronaviruse/who-china-joint-mission-on-covid-19-finalreport.pdf

9 Yung-Yung Chang, The Post-Pandemic World: between Constitutionalized and Authoritarian Orders - China's Narrative-Power Play in the Pandemic Era, Journal of Chinese Political Science (2020), 12 October 2020.

10 Lindsay Maizland, Thamine Nayeem, Anu Kumar, What a Global Health Survey Found Months Before the Coronavirus Pandemic?, Council on Foreign Relations, 24 March 2020, Available at: https://www.cfr.org/inbrief/what-global-health-survey-found-months-coronavirus-pandemic

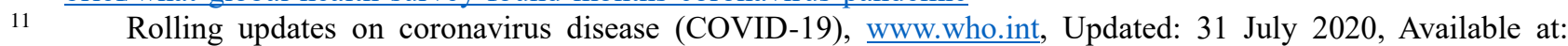
https://www.who.int/emergencies/diseases/novel-coronavirus-2019/events-as-they-happen

12 Kang-Xing Jin, Head of Health, Keeping People Safe and Informed About the Coronavirus, about.fb.com, 18 December 2020, Available at: https://about.fb.com/news/2020/12/coronavirus/ 
regression and the invocation of the international inability to produce quick and effective solutions to the extent of curing sometimes with this impotence, This threatens to reconsider the feasibility of the Union, with the possibility of other countries leaving the European Union other than Britain, such as Italy, Spain and Portugal, such as Italy, Spain and Portugal, based on what has been recorded of the growing public anger against the European Union in many European countries, especially Italy. Concerning the reactions accompanying the rejection of the European Union in March 2020, the request of nine European countries, including Italy, to issue so-called Corona bonds to mitigate the economic effects of the epidemic, as it has become expected to reassess the idea of the union, as well as redefine the institutional function of such regional blocs in general in Unconventional security threats continued to grow ${ }^{13}$.

Perhaps the question now is: Has the Corona pandemic demonstrated the fragility and weakness of the European Union? Is it possible for things to return to normal after the end of the crisis? And to what extent has the crisis affected the European awareness of the Union and its importance, an awareness that has been formed and established over many years and countless negotiations to her?

\section{4. Toward a less globalized world? ... Or will the post-Corona world be more global?}

The aforementioned changes and features reflect the extent of the transformations that have been reflected in all countries of the world without discrimination, and the effect of this on changing concepts and assumptions will certainly not return to what they were. A number of axioms have fallen or need to be reconsidered due to what the pandemic of the time has brought to our world. In this regard, there are two trends, as there are those who say that this epidemic will produce a less globalized world, and on the other hand, others say that the post-Corona world will be more globalized ${ }^{14}$.

To the extent that the globalization system has transformed the globe into a global village so that it facilitates the movement of people, the epidemic has spread without the need to obtain permission or a visa, with the evidence that the epidemic started in a specific region of China and then moved within days to the rest of the world across continents, and the paradox here is that globalization With its political, economic and cultural dimensions, it used to serve international capitalist regimes and are employed to serve goals and projects that are particularly in their interest at the expense of the poor from countries and peoples, but with the Corona virus, any class differences were excluded, and the regimes and those representing them in the power hierarchy were not far from its risks, and thus the epidemic became transient. For social classes with all their

13 Emily A Holmes, and others, Multidisciplinary research priorities for the COVID-19 pandemic: a call for action for mental health science, POSITION PAPER| VOLUME 7, ISSUE 6, P: 547-560, JUNE 01, 2020, Available at: https://www.thelancet.com/journals/lanpsy/article/PIIS2215-0366(20)30168-1/fulltext

14 The Post-COVID-19 World Will Be Less Global and Less Urban, wharton.upenn.edu, 13 May 2020, Available at: https://knowledge.wharton.upenn.edu/article/post-covid-19-world-will-less-global-less-urban/ 
classifications, there is no difference between continents except in the rates of injuries and methods of dealing with the pandemic ${ }^{15}$.

It follows from this that if we are facing a global epidemic, the solution and treatment must be of the same nature, and no country will feel safe unless this epidemic is eliminated or substantially reduced throughout the world. Otherwise, its return will remain possible and this requires documentation. Bonds of global cooperation and the standing of all countries in the world on one front in combating the epidemic. This indicates, for example, that there is international cooperation in clinical testing procedures for people with the disease to ensure the effectiveness of the vaccine being tested ${ }^{16}$.

In a completely opposite way, there is a view that the post-Corona world will be less globalized, and that theory is based on the fact that the current openness of the world and the elimination of the prestige of political borders were among the reasons for the spread of the pandemic in this way. Followers of this trend say that this epidemic could have remained in the epicenter in which it originated and not moved to different regions of the world had we not lived in this globalization, and the proponents of this trend seem happy with the closure of borders and the transformation of the world into isolated islands to confirm the correctness of their position ${ }^{17}$.

The clear truth is that the Coronavirus has been like uneven bikes, a retreat from the tide of globalization and the reduction of interdependence between countries, as the outbreak of the virus has contributed to highlighting the negative aspects of globalization, such as the rapid transmission of diseases, so that every country tends to reduce interdependence or integration with other countries $^{18}$.

The crisis has highlighted the growing factors of self-undermining in the structure of the globalized system, and the most important of these indications is that the strengthened dynamics of human communication that allowed the benefits of globalization to spread is clearly evident that they themselves can allow the spread of the grave challenges to the security of states and societies in a way that cannot be contained except by stopping an important part of the dynamics of communication. Those are the same from work, and the inability to depend completely on the pattern of sharing production processes globally faces a formidable challenge in light of the paralysis that threatens the entire international economy, and in light of the need to impose a blockade on some of its main pillars, as it began in the case of China ${ }^{19}$.

But if we talk about globalization as a matter greater than supply chains across continents, huge container ships and the integration of global markets, then talking about the end of globalization is a

15 Sanni Yaya, Akaninyene Out, Ronald Labonté, Globalisation in the time of COVID-19: repositioning Africa to meet the immediate and remote challenges, Globalization and Health volume 16, Article number: 51 (2020), Published: 24 June 2020, Available at: https://globalizationandhealth.biomedcentral.com/articles/10.1186/s12992-020-00581-4

16 Kang-Xing Jin, Head of Health, Keeping People Safe and Informed About the Coronavirus, Reference already mentioned

17 Steven A. Altman, Will Covid-19 Have a Lasting Impact on Globalization?, Harvard Business Review, 20 May 2020, Available at: https://hbr.org/2020/05/will-covid-19-have-a-lasting-impact-on-globalization

18 Henry Farrell, Abraham Newman, Will the Coronavirus End Globalization as We Know It?, Foreign Affairs, 16 March 2020, Available at: https:/www.foreignaffairs.com/articles/2020-03-16/will-coronavirus-end-globalizationwe-know-it

19 Trey Layton, COVID-19 in The New Age of Global Integration, Harvard Politics, 26 April 2020, Available at: https:/harvardpolitics.com/coronavirus-globalization/ 
path of slogans, especially in light of the tyranny of the communications and information revolution that the world is witnessing and the intertwining of international interests that imposes more International cooperation to confront many issues that cannot be faced individually. However, what is required in this context is to reconsider how to enhance the opportunities provided by globalization so that these opportunities are in the interest of all countries and not in the interest of only a few groups, and at the same time strengthening the tools to address the challenges created by globalization, as the Corona pandemic has revealed the fragility of the system. Global and his impotence in the face of issues of health and solidarity ${ }^{20}$.

\section{Conclusion:}

- The Corona pandemic crisis revealed major imbalances in the health, economic and political governance systems in many countries of the world, and major countries have not escaped from this fast-spreading pandemic due to the unwillingness of their systems to deal with such crises, while poor countries with modest infrastructure have demonstrated their skill in coordination. And the mobilization of its human energies to face the danger of its spread.

- The world after Corona will not be the same as the world before it, the economies of countries will recover to varying degrees determined by the ability to respond to the needs of the next stage, and the priorities of spending and investment will change and the perception of individuals for life systems that have been accustomed to, and then a set of questions arise related to the fate of what humanity has accomplished within the framework of its overlap and perhaps Its economic integration in the past three decades, will the Corona pandemic be the beginning of the restoration of the economic and service systems in the countries of the world?.

- The Corona pandemic crisis restored a degree of confidence between citizens and the state, and even helped to think about returning to the nation state in light of the decline in the influence of the liberal state. Central nation states have proven that they are the most capable of dealing with the critical crises that threaten the survival of peoples in the absence of mechanisms of cooperation and regional integration And the international crisis, as the crisis raised new questions related to the type of political systems and their utility in dealing with the crisis, as authoritarian or semi-authoritarian states have had little difficulty in implementing this policy, as for democracies and quasi-democracies, the form and nature of intervention opened new horizons about the nature of the future role of the state, the controls of its intervention and the limits of this Interfering with personal and civil liberties.

- It has come to be recognized that the international system has been witnessing multi-polarity for years, and that the Corona pandemic has only entrenched an international reality that is already in the process of forming while giving more opportunities for the rise of China and the decline of the United States of America. However, this does not necessarily mean that China will automatically replace the United States of America. Rather, the United States will likely remain the global leader for decades to come.

20 Jesse B Bump, Et al, International collaboration and covid-19: what are we doing and where are we going?, www.bmj.com, BMJ 2021; 372 doi: https://doi.org/10.1136/bmj.n180, (Published 29 January 2021), Available at: https://www.bmj.com/content/372/bmj.n180 


\section{3rd International Conference on Future of}

BUSINESS, MANAGEMENT \& ECONOMICS

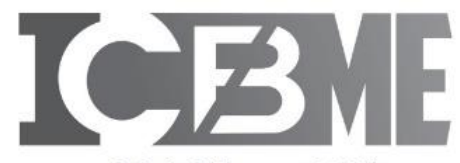

04-06 June, 2021

Barcelona, Spain

- The Corona pandemic crisis revealed the failure of international and national systems and regional blocs to deal with the health challenge caused by the rapid spread of the virus and the lack of accurate scientific knowledge about it, so it is expected that after the pandemic recedes, the feasibility of the structures of regional blocs, especially the European Union, will be reviewed. The state of rift in the structure of the union in conjunction with the trends of national and right-wing currents towards closing in on the self and focusing on the national interest without considering considerations of regional responsibility, parallel with the rise of waves of national populism behind the walls of national regression and the invocation of the international inability to produce quick and effective solutions to the extent of sometimes curing this deficit, This may threaten a reconsideration of the feasibility of the Union, with the possibility of other countries leaving the European Union other than Britain, such as Italy, Spain and Portugal, such as Italy, Spain and Portugal, based on what has been recorded of the growing public anger against the European Union in many European countries, especially Italy.

- As much as the globalization system has transformed the globe into a global village so that it facilitates the movement of people, the Corona epidemic has spread without the need to obtain permission or a visa, with the evidence that the epidemic started in a specific region of China and then moved within days to the rest of the world across continents, and the paradox here is that Globalization, in its political, economic and cultural dimensions, was serving international capitalist regimes and being employed to serve goals and projects that are particularly in their interest at the expense of the poor from countries and peoples, but with the Corona virus no class differences were eliminated and the regimes and those representing them in the power hierarchy were not far from its risks, and thus the epidemic became Crossing social classes, with all their classifications, there is no difference between continents except in the rates of injuries and methods of dealing with the pandemic. 


\section{References}

1. Altman, S. A. (20 May 2020). Will Covid-19 Have a Lasting Impact on Globalization? Harvard Business Review. Available at: https://hbr.org/2020/05/will-covid-19-have-alasting-impact-on-globalization.

2. Chang, Y.-Y. (12 October 2020). The Post-Pandemic World: between Constitutionalized and Authoritarian Orders - China's Narrative-Power Play in the Pandemic Era. Journal of Chinese Political Science (2020).

3. Emily A Holmes, and others. (JUNE 01, 2020). Multidisciplinary research priorities for the COVID-19 pandemic: a call for action for mental health science. POSITION PAPER VOLUME 7, ISSUE 6 (pp. P: 547-560). Available at: https://www.thelancet.com/journals/lanpsy/article/PIIS2215-0366(20)30168-1/fulltext.

4. Henry Farrell, Abraham Newman. (16 March 2020). Will the Coronavirus End Globalization as We Know It? Foreign Affairs. Available at: https://www.foreignaffairs.com/articles/202003-16/will-coronavirus-end-globalization-we-know-it.

5. Jesse B Bump, Et al. ((Published 29 January 2021)). International collaboration and covid19: what are we doing and where are we going? www.bmj.com, BMJ 2021; 372 doi: https://doi.org/10.1136/bmj.n180. Available at: https://www.bmj.com/content/372/bmj.n180.

6. Layton, T. (26 April 2020). COVID-19 in The New Age of Global Integration. Harvard Politics. Available at: https://harvardpolitics.com/coronavirus-globalization/.

7. Lindsay Maizland, Thamine Nayeem, Anu Kumar. (24 March 2020). What a Global Health Survey Found Months Before the Coronavirus Pandemic? Council on Foreign Relations. Available at: https://www.cfr.org/in-brief/what-global-health-survey-found-monthscoronavirus-pandemic.

8. MARZOCCHI, O. (Manuscript completed in June 2020). Policy Department for Citizens' Rights and Constitutional Affairs, THE IMPACT OF CORONAVIRUS MEASURES ON DEMOCRACY, RULE OF LAW AND FUNDAMENTAL RIGHTS IN THE EU, (An overview of the measures taken by EU Member States). Available via: https://www.europarl.europa.eu/cmsdata/211286/Overview\%20Covid\%20Measures\%20DR F\%2014\%20LIBE.pdf.

9. OECD Policy Responses to Coronavirus (COVID-19),. (10 Nov 2020). The territorial impact of COVID-19: Managing the crisis across levels of government.

http://www.oecd.org/coronavirus/policy-responses/the-territorial-impact-of-covid-19managing-the-crisis-across-levels-of-government-d3e314e1/.

10. Report of the WHO-China Joint Mission on Coronavirus Disease 2019 (COVID-19). (16-24 February 2020). (p. P; 24). Available at: https://www.who.int/docs/defaultsource/coronaviruse/who-china-joint-mission-on-covid-19-final-report.pdf.

11. Rolling updates on coronavirus disease (COVID-19). (Updated: 31 July 2020). www.who.int. Available at: https://www.who.int/emergencies/diseases/novel-coronavirus2019/events-as-they-happen. 


\section{3rd International Conference on Future of \\ BUSINESS, MANAGEMENT \& ECONOMICS}

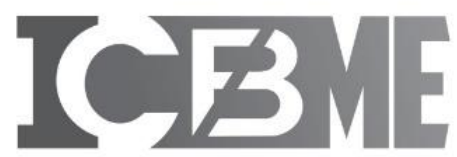

04-06 June, 2021

Barcelona, Spain

12. Sanni Yaya, Akaninyene Out, Ronald Labonté. (Published: 24 June 2020). Globalisation in the time of COVID-19: repositioning Africa to meet the immediate and remote challenges. Globalization and Health volume 16, Article number: 51 (2020). Available at: https://globalizationandhealth.biomedcentral.com/articles/10.1186/s12992-020-00581-4.

13. SCCM Resources. (5 Dec 2020). United States Resource Availability for COVID-19, SCCM. Available at: https://www.sccm.org/Blog/March-2020/United-States-ResourceAvailability-for-COVID-19.

14. The Post-COVID-19 World Will Be Less Global and Less Urban. (13 May 2020). wharton.upenn.edu. Available at: https://knowledge.wharton.upenn.edu/article/post-covid19-world-will-less-global-less-urban/.

15. Xue Li, Cheng Zhangxi. (28 April 2018). Will China Replace the US Global Role? the diplomat. Available at: https://thediplomat.com/2018/04/will-china-replace-the-us-globalrole/.

16. Yang, S. X. (22 November 2020). Complexity in China's current role in multilateral orders, . (pp. pages288-305(2020)). China International Strategy Review volume 2.

17.Zielonka, J. (26 Mar 2020). Has the coronavirus brought back the nation-state? Social Europe. Available at: https://www.socialeurope.eu/has-the-coronavirus-brought-back-thenation-state. 